\title{
フープストレス一定条件下での高磁場マグネット設計
}

\author{
大塚 昭弘 ，木吉 司
}

\section{Design of a High-field Magnet under Constant Hoop Stress}

\author{
Akihiro OTSUKA ${ }^{\dagger}$ and Tsukasa KIYOSHI
}

\begin{abstract}
Synopsis: Hoop stress is a very important factor in the design of multi-solenoid magnets. Designs of high-field magnets in the range of $23.5 \mathrm{~T}$ to $30.5 \mathrm{~T}$ were researched. It was confirmed that the designs were strongly limited by the design criteria of hoop stress. A modeling magnet consisting of multi-coils has been assumed for the calculation of several properties under the condition that the maximum hoop stress of every coil has the same value. The calculation results show that there are certain relationships among the central magnetic field $B_{0}$, the magnet volume, and the stored energy. The results show that these values correlate with the exponential of $B_{0}^{2}$.
\end{abstract}

Keywords: current density, hoop stress, high magnetic field, solenoid coil, superconductor

\section{1. はじめに}

NMR の高性能化に向けて NMR 用マグネットは高磁場 化が進められてきた。物質・材料研究機構では 2001 年に $920 \mathrm{MHz}(21.6 \mathrm{~T})$ マグネットを ${ }^{1)}$ 2)、2004 年に $930 \mathrm{MHz}$ (21.9 T)マグネットを相次いで完成させた ${ }^{3)}{ }^{4)}$ 。その後、 オックスフォード・インストゥルメンツ社やブルカーバイ オスピン社が $950 \mathrm{MHz}(22.3 \mathrm{~T})$ マグネットの開発に成功し ている。これらのマグネットには従来からの NbTi および $\mathrm{Nb}_{3} \mathrm{Sn}$ 超伝導線が使われた。

最近、Bi 系や Y 系の高温超伝導線材 (HTS) の開発が 進み、実用に耐える特性や長尺の線材が得られるようにな りつつある 5) 6)。これらの成果により HTS を使用した 25 $\mathrm{T}$ 以上の超伝導マグネットの実現性が高まり、一部の研究 機関では NMR 用 $30 \mathrm{~T}$ 超伝導マグネットの検討が進めら れている 7)。文献 7)で述べられている $30 \mathrm{~T}$ マグネットの 設計は Bi-2212 の円形線材を想定しており、HTS で分担す る磁場は $10 \mathrm{~T}$ となっている。 HTS コイルのデザインマー ジンは臨界電流の $70 \%$ で、 $0.275 \%$ までの歪を許容する設 計となっている。これは補強材のヤング率から計算すると $206 \mathrm{MPa}$ のストレスに相当する。動作温度は $4.2 \mathrm{~K}$ おび $1.8 \mathrm{~K}$ で検討しているが、HTS の温度依存性はないとして いる。

Received April 4, 2007

(独) 物質・材料研究機構

厂305-0003 茨城県つくば市桜 3-13

National Institute for Materials Science, 3-13 Sakura, Tsukuba,

Ibaraki 305-0003, Japan

† E-mail: OTSUKA.Akihiro@nims.go.jp
このような状況の中で、筆者らも 25〜30 T 規模のマグ ネットについてフィージビリティスタディを行っており、 本報ではマグネットの基本設計およびモデルマグネットを 用いた磁場解析の結果について報告する。NMR 用マグ ネットの場合高い磁場均一度が要求され、軸上磁場分布に おける 2 次、4 次、6 次の不均一成分を打ち消すための補 正コイルが必要となる。920 MHz、930 MHz マグネットで はコイルの最外層部に補正コイルを設置したが、文献 7) では HTS の最外層コイルを分割して補正コイルとしてい る。このように補正コイルの配置にはいろいろな案があり、 メインコイルの大きさ等を考慮した最適な設計が要求され る。このため本報では補正コイルの設計を行っていないが、 $10 \mathrm{~mm}$ 球の磁場均一度が $25 \mathrm{ppm}$ 未満になるようにコイル 長さを設定している。

通常、マグネットの運転電流は超伝導線材の臨界電流值 で決められる。しかし、高磁場を発生させようとすると、 後述するように、線材の経験磁場が高い領域では臨界電流 值で制限されるが、経験磁場が少しでも下がると臨界電流 值よりもむしろ線材に働く電磁力（特にフープストレス） で制約されるようになる。特に、中低磁場領域にある $\mathrm{Nb}_{3} \mathrm{Sn}$ や $\mathrm{NbTi}$ コイルにおいてはこの傾向が顕著であるこ とが明らかとなった。

そこでコイルに加わる簡便な電磁力の指標としてフープ ストレスを使用し、超伝導線材の臨界電流值には関わらず フープストレスだけで制約された場合のマグネット設計を 行い、発生する磁場とコイル体積や蓄積エネルギー等との 関係について解析を行った。 


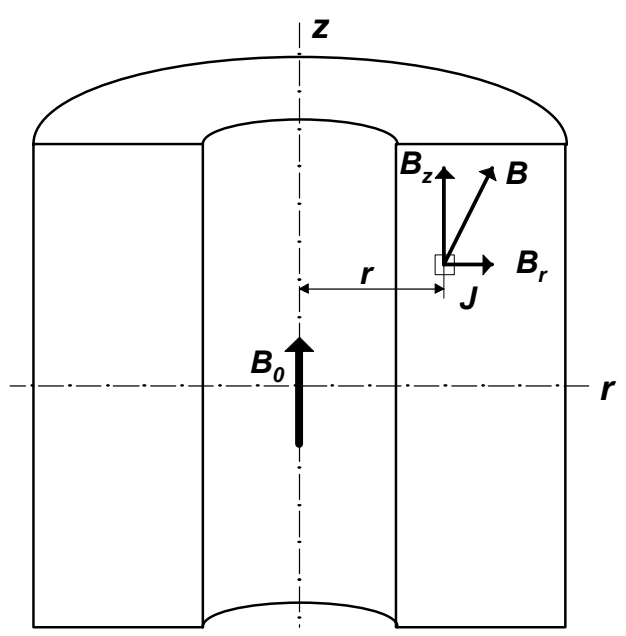

Fig. 1 Cross-section of a solenoid coil. $\sigma_{h}$ is defined by $B_{\mathrm{z}} \times J \times r$.

フープストレスで制約されたマグネットについては、物 性研究用パルスマグネットの開発過程で M. Dateにより多 層コイル法が発案されている ${ }^{8)}$ 。この方法によると、コイ ルを多層にすることでコイルを破壊させることなく無限大 の磁場を発生させることが可能である。無限長コイルを無 限に分割した場合、コイル内半径 : $\boldsymbol{r}_{\boldsymbol{0}}$ 、コイル外半径 : $\boldsymbol{R}_{\boldsymbol{0}}$ と中心磁場 $: \boldsymbol{B}_{\boldsymbol{0}}$ には次の関係があることが指摘されてい る。

$$
B_{0} \propto \sqrt{2 \times \log \left(R_{0} / r_{0}\right)}
$$

今回は有限長コイルを設定し、実際にコイル内のフープ ストレスを数值計算で求めることにより解析を行った。 フープストレス： $\sigma_{\boldsymbol{h}}$ は Fig. 1 に示すようにコイル内のあ る点における経験磁場の Z 方向成分 : $\boldsymbol{B}_{z}$ と電流密度 : $\boldsymbol{J}$ お よび半径 : $\boldsymbol{r}$ の積で与えられるとし、各要素間の力の伝達 は無視している。

$$
\sigma_{h}=B_{z} \times J \times r
$$

\section{H T S を使った高磁場マグネットの基本設計}

\section{1 設計条件}

$23.5 \sim 30.5 \mathrm{~T}$ （プロトンの核磁気共鳴周波数で $1 \sim 1.3$ $\mathrm{GHz}$ に相当する）の磁場を発生させるマグネットの基本 設計を行った。NMR として使用することを前提に室温空 間の直径は $54 \mathrm{~mm}$ とした。マグネットの冷却には加圧超 流動へリウム方式を採用し、2 K での運転を行うとした。 使用する線材の種類は HTS、 $\mathrm{Nb}_{3} \mathrm{Sn} 、 \mathrm{NbTi} の 3$ 種類で、 それぞれの設計条件は次のとおりである。今回の基本設計 では、この条件を満たすように線材の寸法を変えてグレー ディングを行っている。

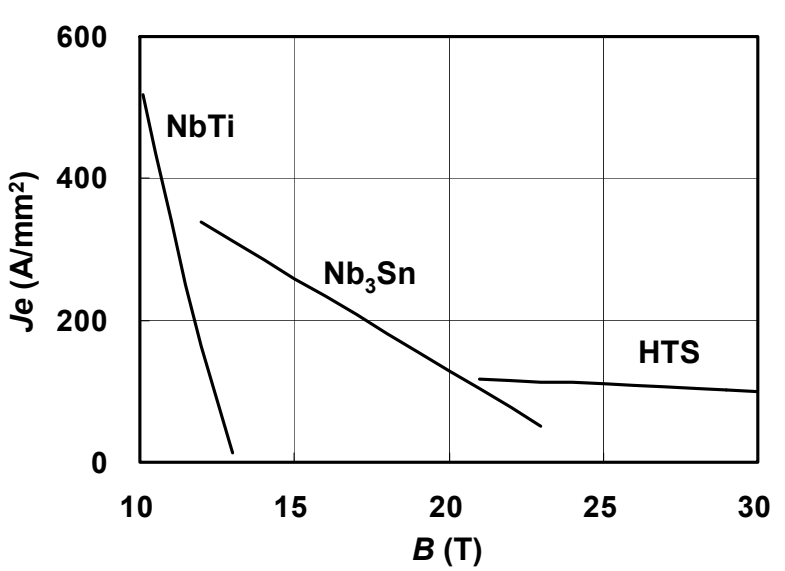

Fig. 2 Critical current densities of superconductors used for the magnet designs at $2 \mathrm{~K}$.

1)HTS コイル

HTS コイルはマトリクス材に銀を使用した Bi-2223 線材 を想定し、導体全体の断面積でみた臨界電流密度： $\boldsymbol{J} \boldsymbol{e}=120 \mathrm{~A} / \mathrm{mm}^{2}$ (20T)、Je $=100 \mathrm{~A} / \mathrm{mm}^{2}$ (30T)の值を用いた。 これは最近の報告されている值と比較すると低い值だが ${ }^{9}$ 、 長尺線の場合の特性のばらつきや補強材による強化も配慮 し、実現性の高い值として設定した。線材は幅 $4.3 \mathrm{~mm} \times$ 厚さ $0.22 \mathrm{~mm}$ のテープ線材を想定し、重ねる枚数を変える ことでグレーディングを行った。臨界電流值に対する運転 電流の比率：Iop/Ic は $75 \%$ 以下を、 $\sigma_{\boldsymbol{h}}$ は $170 \mathrm{MPa}$ 以下を 目標とした。

2) $\mathrm{Nb}_{3} \mathrm{Sn} コ$ コイ

$920 \mathrm{MHz} 、 930 \mathrm{MHz}$ マグネットの製作に使用した線材と 同じ $\mathrm{Cu} / \mathrm{nonCu}=0.3$ のブロンズ法外部安定化線材を想定し、 ワインドアンドリアクト（W\&R）法で製作するとした ${ }^{4)}$ $16 \% \mathrm{Sn}$ ブロンズの $2 \mathrm{~K}$ での $\boldsymbol{J e}$ の值は、Je $=77 \mathrm{~A} / \mathrm{mm}^{2}(22$ $\mathrm{T}) 、 \boldsymbol{J} \boldsymbol{e}=51 \mathrm{~A} / \mathrm{mm}^{2}(23 \mathrm{~T})$ を用いた。 $\mathrm{Nb}_{3} \mathrm{Sn}$ コイルの最大経 験磁場は $22.5 \mathrm{~T}$ 以下になるようにした。Iop/Ic は 75\%以 下を、 $\sigma_{\boldsymbol{h}}$ は $200 \mathrm{MPa}$ 以下を目標とした。

3) $\mathrm{NbTi}$ コイル

$\mathrm{Cu} / \mathrm{S}=1.3$ の $\mathrm{NMR}$ 用超伝導線の $4.2 \mathrm{~K}$ での $\boldsymbol{I} \boldsymbol{c}$ を基準にし、 $2 \mathrm{~K}$ まで冷却することで $2.5 \mathrm{~T}$ 分高磁場側にシフトさせた 值を用いた。 NbTi の最大経験磁場は $12 \mathrm{~T}$ 以下となるよう にした。 $\sigma_{\boldsymbol{h}}$ は $230 \mathrm{MPa}$ 以下を目標とした。

現時点では HTS 線材、特に Bi 系線材で、低電流領域で も無視できない電圧が発生していること、および超伝導接 続技術が確立していないことを考慮すると、マグネットは 常時電源で駆動する方式で運転されると考えられる。この ことは $\mathrm{Nb}_{3} \mathrm{Sn}$ コイルや $\mathrm{NbTi}$ コイルにおいて、Iop/Ic と $\mathrm{n}$ 值の相関で決定される永久電流モード運転時のドリフト值 （磁場減衰率）を考慮する必要はないことを意味している。 
$\sigma_{h}(\mathrm{MPa})$ Iop/Ic

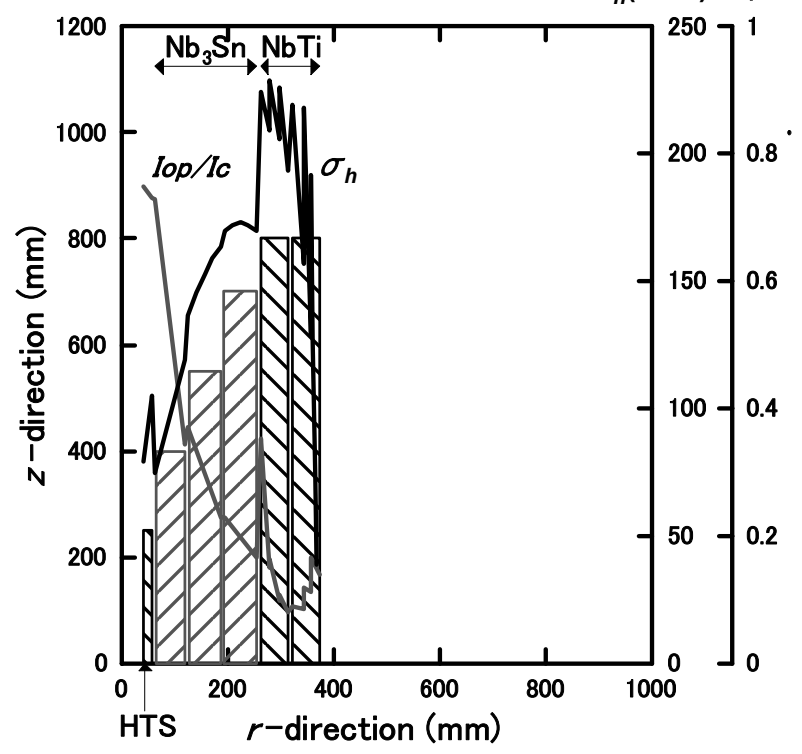

Fig. 3 Cross-section, Iop/Ic and $\sigma_{h}$ of a $\boldsymbol{B}_{0}=23.5 \mathrm{~T}$ magnet.

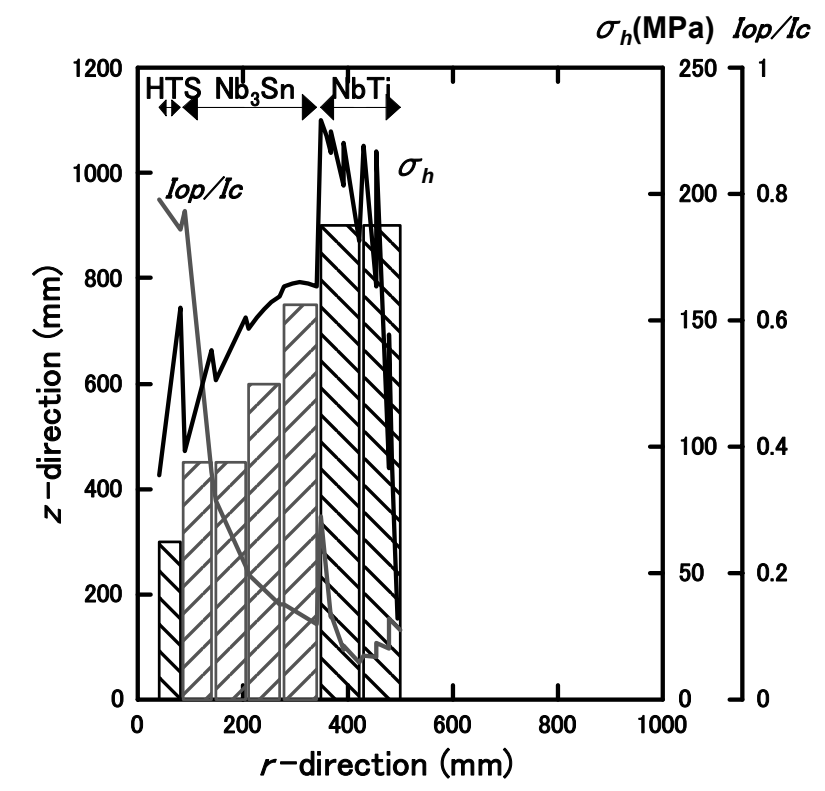

Fig. 4 Cross-section, Iop/Ic and $\sigma_{h}$ of a $\boldsymbol{B}_{0}=25.8 \mathrm{~T}$ magnet.

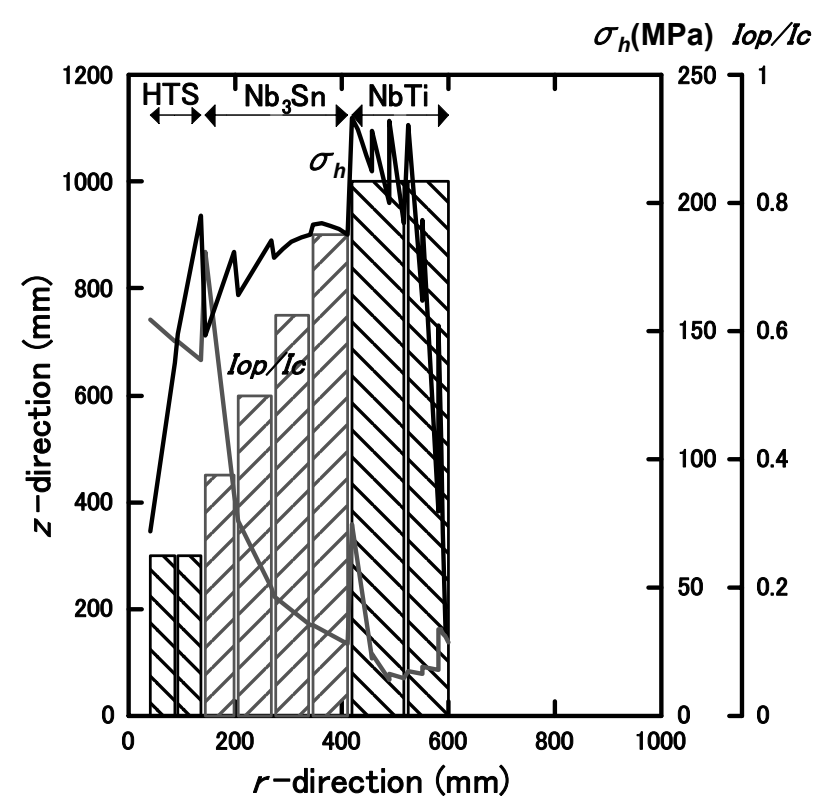

Fig. 5 Cross-section, Iop/Ic and $\sigma_{h}$ of a $\boldsymbol{B}_{0}=28.2 \mathrm{~T}$ magnet.

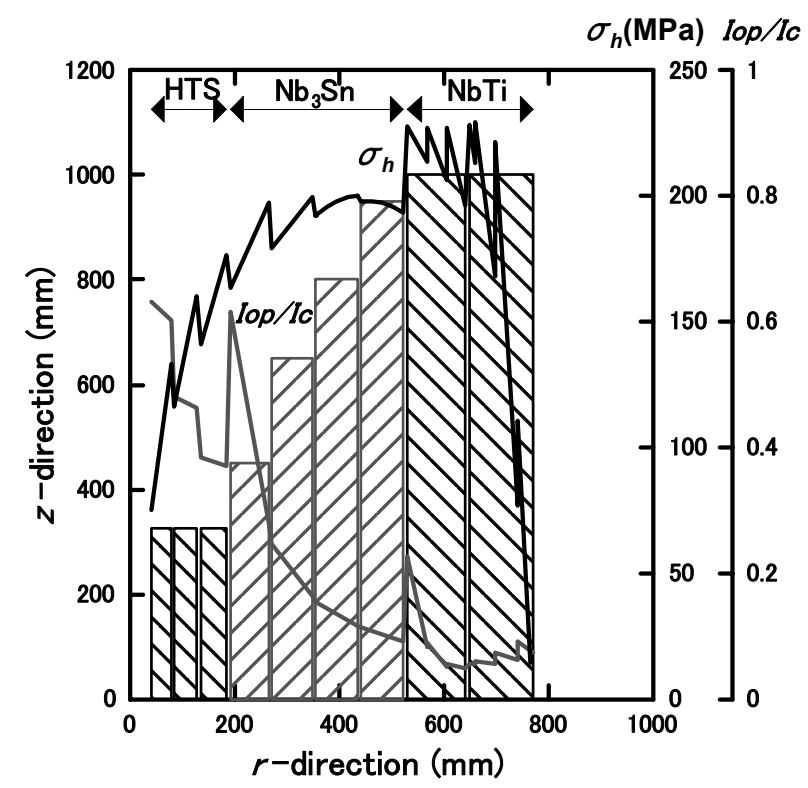

Fig. 6 Cross-section, Iop/Ic and $\sigma_{h}$ of a $\boldsymbol{B}_{0}=29.4 \mathrm{~T}$ magnet.

Table 1 Summary of high-field magnet designs using HTS.

\begin{tabular}{|c|c|c|c|c|c|c|c|c|c|c|c|}
\hline \multirow{2}{*}{$\begin{array}{c}\text { Magnetic } \\
\text { Field } \\
(\mathrm{T})\end{array}$} & \multirow{2}{*}{$\begin{array}{c}{ }^{1} \mathrm{H} \\
\text { Frequency } \\
(\mathrm{GHz})\end{array}$} & \multirow{2}{*}{$\begin{array}{c}\text { Inner } \\
\text { Diameter } \\
(\mathrm{mm})\end{array}$} & \multirow{2}{*}{$\begin{array}{c}\text { Outer } \\
\text { Diameter } \\
(\mathrm{mm})\end{array}$} & \multirow[b]{2}{*}{$\begin{array}{l}\text { Length } \\
(\mathrm{mm})\end{array}$} & \multirow{2}{*}{$\begin{array}{c}\text { Stored } \\
\text { Energy } \\
(\mathrm{MJ})\end{array}$} & \multicolumn{4}{|c|}{ Weight of Superconductors } & \multicolumn{2}{|c|}{ Stray Field $(0.5 \mathrm{mT})$} \\
\hline & & & & & & $\begin{array}{l}\text { HTS } \\
(\mathrm{kg})\end{array}$ & $\begin{array}{c}\mathrm{Nb}_{3} \mathrm{Sn} \\
(\mathrm{kg})\end{array}$ & $\begin{array}{c}\mathrm{NbTi} \\
(\mathrm{kg})\end{array}$ & $\begin{array}{l}\text { Total } \\
(\mathrm{kg})\end{array}$ & $\begin{array}{l}\text { Axial } \\
(\mathrm{m})\end{array}$ & $\begin{array}{c}\text { Radial } \\
\text { (m) }\end{array}$ \\
\hline 23.49 & 1.00 & 80 & 745 & 1600 & 40 & 17 & 1592 & 2269 & 3878 & 13.8 & 10.9 \\
\hline 25.84 & 1.10 & 80 & 997 & 1800 & 81 & 63 & 2958 & 4800 & 7821 & 17.6 & 13.9 \\
\hline 28.20 & 1.20 & 80 & 1199 & 2000 & 147 & 212 & 4912 & 7821 & 12945 & 21.0 & 16.6 \\
\hline 29.39 & 1.25 & 80 & 1542 & 2000 & 257 & 449 & 8475 & 13591 & 22515 & 25.3 & 20.0 \\
\hline 30.53 & 1.30 & 80 & 1724 & 2200 & 355 & 624 & 10702 & 19049 & 30375 & 28.2 & 22.3 \\
\hline
\end{tabular}




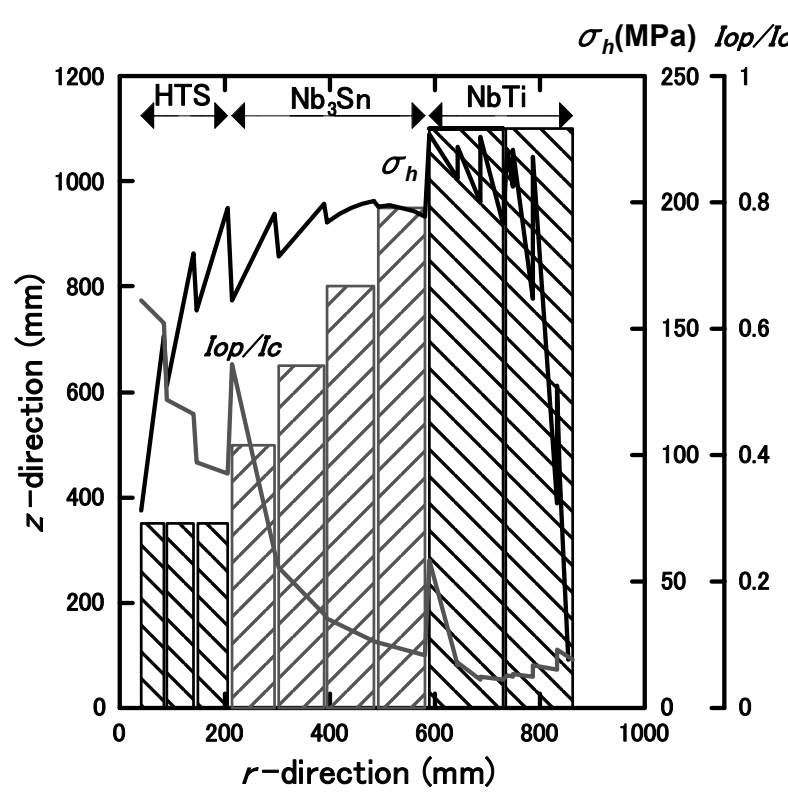

Fig. 7 Cross-section, Iop/Ic and $\sigma_{h}$ of a $\boldsymbol{B}_{0}=30.5 \mathrm{~T}$ magnet.

以上の理由より、今回の設計では $I o p / I c$ は永久電流 モード運転のNMRマグネットと比べて高めに設定した。

設計に用いた臨界電流密度：Je のデータを Fig. 2 に示 す。

\section{2 設計例}

設計した 23.5〜30.5 T のマグネットの断面および Iop/Ic、 $\sigma_{\boldsymbol{h}}$ をプロットしたものを Fig. 3〜 7 に示す。

$I o p / I c$ および $\sigma_{h}$ 共にコイルの Z 軸方向の位置で值は変 わってくるが、ここでは、軸に沿った最大值をプロットし ている。また、これらの值は線サイズが変わる所で不連続 になるが、判りやすくするため連続したグラフとして表示 した。これらの設計で得られた、コイル寸法、蓄積エネル ギー、線材質量等を Table 1 に示す。

これらの設計例において、特徵的なのは次の点である。

- HTS コイル、 $\mathrm{Nb}_{3} \mathrm{Sn}$ コイル、 $\mathrm{NbTi}$ コイルのいずれも Iop/Ic が高い地点は、それぞれの最内層部である。

- 最内層部より少しでも外側の磁場の低い所では、電流密 度は $\sigma_{\boldsymbol{h}}$ で制約されている。

・ NbTi コイルの場合だと Iop/Ic は最内層部でも 0.35 であ り、全ての領域において $\sigma_{\boldsymbol{h}}$ で制約されている。

注目すべき点は、線材質量、蓄積エネルギーは磁場が高 くなるにつれて急激に大きくなっていることである。線材 重量に関して $1 \mathrm{GHz}$ マグネットを基準に考えると、1.1 $\mathrm{GHz}$ では2 倍に、1.2 GHz では 3.3 倍に、1.3 GHz では 7.8 倍に増加していく。これはフープストレスの上限を設定し たことに関係する。即ち、フープストレスがコイル設計上 最も大きな制約条件になっていることを示している。そこ でフープストレス一定条件で仮想設計を行い、耐フープス

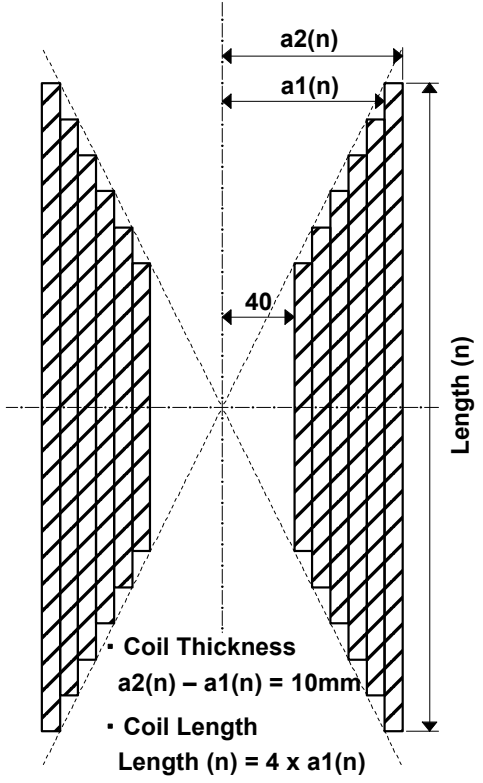

Fig. 8 A model magnet for calculating under constant hoop stress condition.

トレス強化線材が実現した場合のマグネットのコンパクト 化の可能性について検討した。

\section{3. フープストレスで制約されたマグネット}

\section{1 計算手法}

今回の計算にあたって、Fig. 8 に示すような $\mathbf{N}$ 個のコイ ルから成るモデルマグネットを設定した。 $\phi 54 \mathrm{~mm}$ の室 温空間を有する NMR 用マグネットを想定して、コイル最 内径は $\phi 80 \mathrm{~mm}$ とした。各コイルの厚さは $10 \mathrm{~mm}$ とし、 コイル長さはコイル内半径の 4 倍とした。巻き枠や絶縁材 については考慮しないものとした。

マグネットにおける $\mathrm{n}$ 番目のコイルの電流密度 $J(n)$ は次 式で定義されるものとする。

$$
J(n)=\frac{\operatorname{Iop} \times \operatorname{Turn}(n)}{(a 2(n)-a 1(n)) \times \operatorname{Length}(n)}
$$

ここで Iop : 運転電流、Turn(n) : ターン数、a1(n)：コイ ル内半径、 $a 2(n)$ : コイル外半径、Length(n)：コイル長さ である。コイル数 $\mathrm{N}$ と $\boldsymbol{J}(\boldsymbol{n})$ が決まれば、中心磁場 : $\boldsymbol{B}_{\boldsymbol{0}}$ や 各コイルにおける $\sigma_{h \max }(n)$ は一義的に決定される。

このモデルにおいて、フープストレスの值： $\sigma_{h}$ を固定 し、各コイルの $\sigma_{\boldsymbol{h}}$ の最大值 : $\sigma_{\boldsymbol{h}} \max (\boldsymbol{n})$ が全て一定の值と なるように $J(n)$ を計算する。具体的には $J(n)$ の初期值 $\boldsymbol{J}(\boldsymbol{n})^{\mathbf{0}}$ を与え、その時の各コイルにおける $\sigma_{\boldsymbol{h} \text { max }}(n)^{\mathbf{0}}$ を計算 する。この值から次式に従って $J(n)^{1}$ を求め、再度 $\sigma_{h \text { max }}(n)^{1}$ を計算する。 


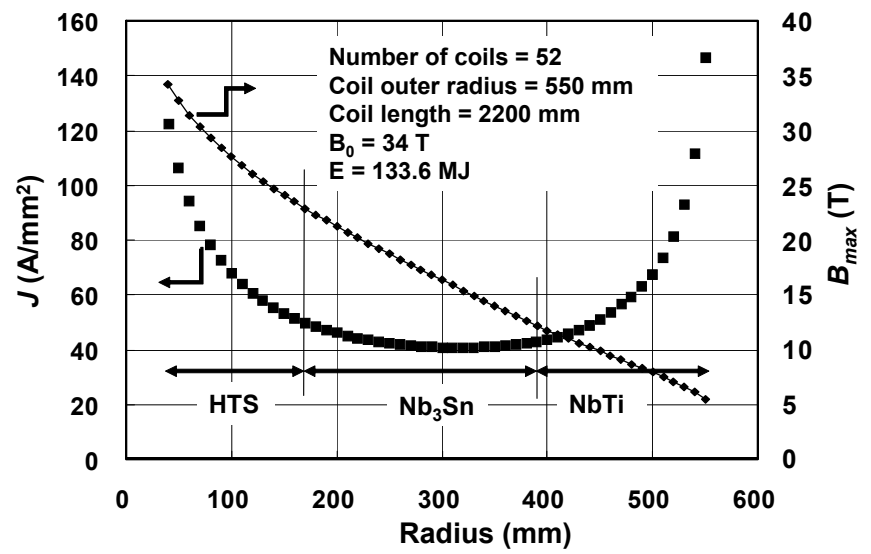

Fig. 9 A calculation example of current densities and peak fields in the case of $\sigma_{h}=200 \mathrm{MPa}$.

$$
J(n)^{m+1}=J(n)^{m} \sqrt{\frac{\sigma_{h}}{\sigma_{h \cdot \max }(n)^{m}}}
$$

これを全てのコイルの $\sigma_{h \max }(n)$ が固定した $\sigma_{h}$ に一致す るまで繰り返す。得られた $\boldsymbol{J}(\boldsymbol{n})$ を使って中心磁場、蓄積エ ネルギーを計算した。

\section{2 計算結果}

\section{2.1 電流密度分布}

$\mathbf{N}=52 、 \sigma_{h}=200 \mathrm{MPa}$ の場合の電流密度分布の計算例を Fig. 9 に示す。この図では各コイルの内半径に対して、電 流密度と最大経験磁場をプロットしている。

コイルの内径側では磁場が強くても径が小さいので電流 密度は高い值を取ることができるが、径が大きくなるにつ れて電流密度は低くなる。更に径が大きくなると経験磁場 が下がってくるので電流密度は再び高くなる。

線材の種類を HTS、 $\mathrm{Nb}_{3} \mathrm{Sn} 、 \mathrm{NbTi}$ とした場合、第 2 章で 設定したのと同様にマグネットを $2 \mathrm{~K}$ で運転するとして $\mathrm{Nb}_{3} \mathrm{Sn} 、 \mathrm{NbTi}$ の最大経験磁場の上限をそれぞれ 22.5T、12T で考えてみる。 $\mathrm{Cu} / \mathrm{S}=1.3$ の $\mathrm{NbTi}$ 線の $12 \mathrm{~T}$ における臨界電 流密度 $\boldsymbol{J e}$ は $160 \mathrm{~A} / \mathrm{mm}^{2}$ 以上なのに対して、コイルの電流密 度は $\boldsymbol{J}=43 \mathrm{~A} / \mathrm{mm}^{2}$ であり $\sigma_{\boldsymbol{h}}$ で制約されていることを意味し ている。同様に $\mathrm{Cu} / \mathrm{nonCu}=0.3$ の $\mathrm{Nb}_{3} \mathrm{Sn}$ では、22.5 T での臨 界電流 $\boldsymbol{J} \boldsymbol{e}=65 \mathrm{~A} / \mathrm{mm}^{2}$ に対して、コイルの電流密度は $\boldsymbol{J}=50$ $\mathrm{A} / \mathrm{mm}^{2}$ なのでこれも $\boldsymbol{\sigma}_{\boldsymbol{h}}$ で制約されている。 $\boldsymbol{\sigma}_{\boldsymbol{h}}$ の基準を上 げると経験磁場の高い所では臨界電流で制約されるように なるが、 $\mathrm{Nb}_{3} \mathrm{Sn} 、 \mathrm{NbTi}$ のカバーする磁場領域を下げると結 局は $\boldsymbol{\sigma}_{\boldsymbol{h}}$ で制約されることになる。

次に $\mathbf{N}=10 、 \sigma_{h}=500 \mathrm{MPa}$ の場合の電流密度分布の計算例 を Fig. 10 に示す。ここまで $\sigma_{\boldsymbol{h}}$ を高く設定しても $20 \mathrm{~T}$ 以上 の領域における電流密度は $300 \mathrm{~A} / \mathrm{mm}^{2}$ 以下に収まってい る。最近、Bi-2223 や $\mathrm{Y}$ 系線材の特性はかなり向上してお り、同程度かこれ以上の臨界電流が報告されている9１0) 11)

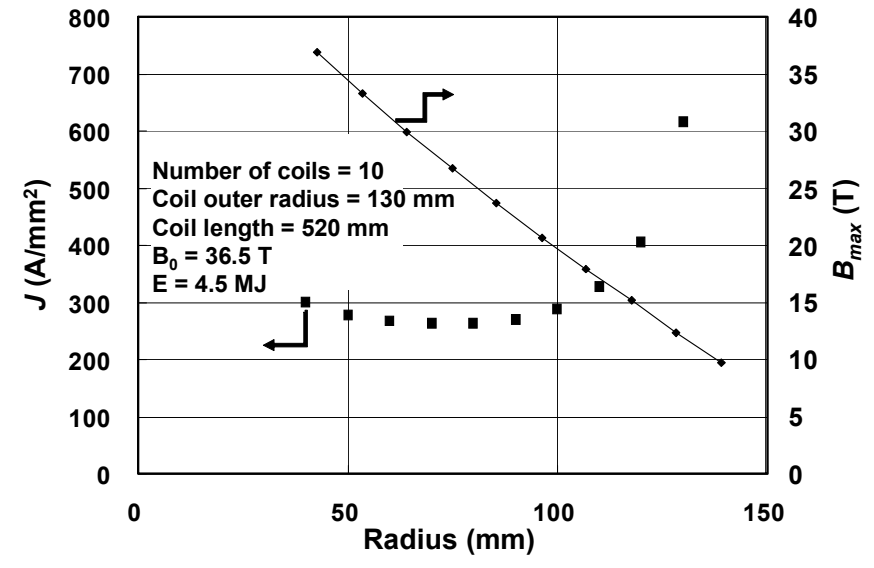

Fig. 10 A calculation example of current densities and peak fields in the case of $\sigma_{h}=500 \mathrm{MPa}$.

以上より、30 T クラスのマグネットを設計する場合、コ イルの電流密度は全ての磁場領域において $\sigma_{\boldsymbol{h}}$ で制約され ることになる。このように考えると $\sigma_{\boldsymbol{h}}$ は非常に重要な設 計基準であると言うことができる。

\subsubsection{B とコイル体積}

$\sigma_{\boldsymbol{h}}$ を 200〜 500 MPa の範囲に設定し、コイル数：Nを 変えて計算を行った。これにより得られた $\boldsymbol{B}_{\boldsymbol{0}}$ とコイル外 半径および $\boldsymbol{B}_{\boldsymbol{0}}$ とコイル体積の関係をそれぞれ Fig. 11 と Fig. 12 に示す。これらの図では横軸を $\boldsymbol{B}_{\boldsymbol{0}}$ の 2 乗で、縦軸 を対数でプロットしている。

これらの計算結果より、無限長コイルにおいて成り立つと された(1)式の関係が有限長コイルにも適用できるだけでな く、 $\boldsymbol{B}_{\boldsymbol{0}}$ とコイル体積との間でも同様の関係が成り立つこと が判った。

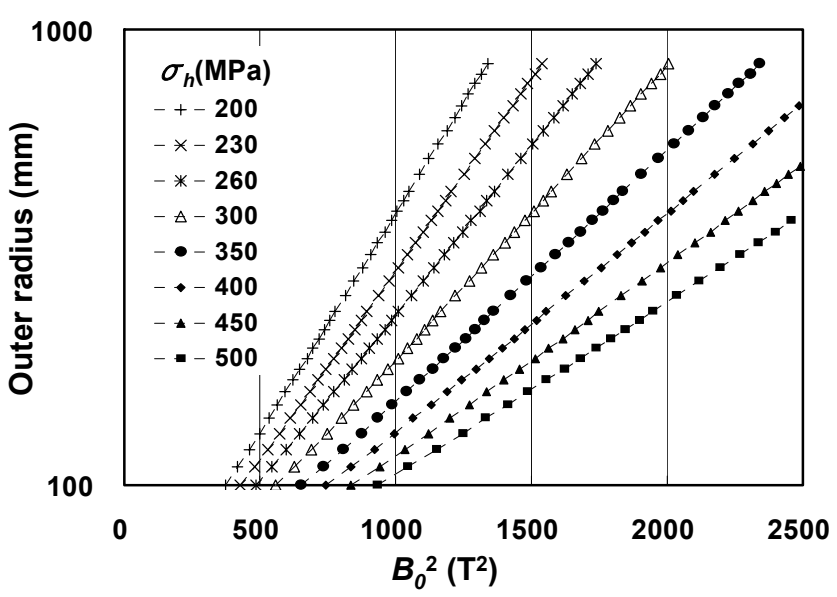

Fig. 11 Relationship between $\boldsymbol{B}_{\boldsymbol{0}}$ and outer radius. 


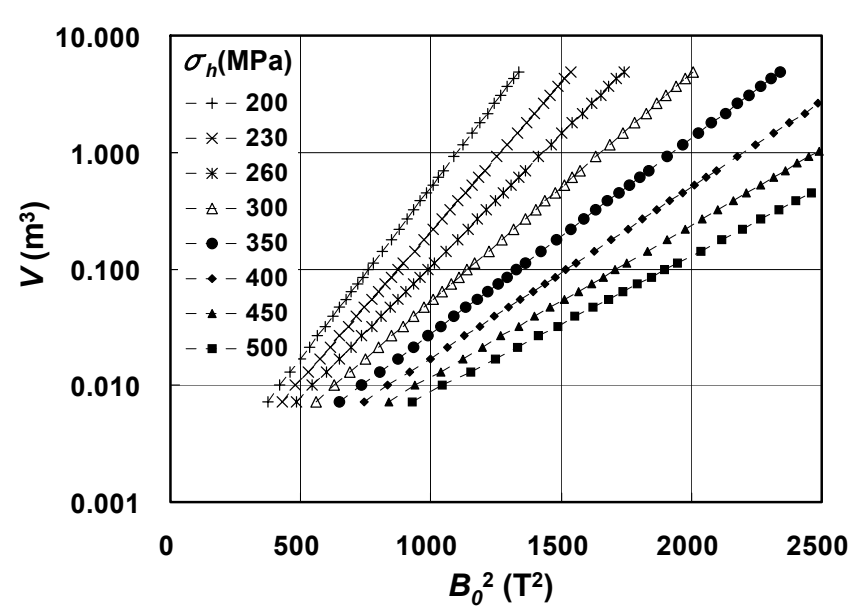

Fig. 12 Relationship between $\boldsymbol{B}_{\boldsymbol{0}}$ and coil volume.

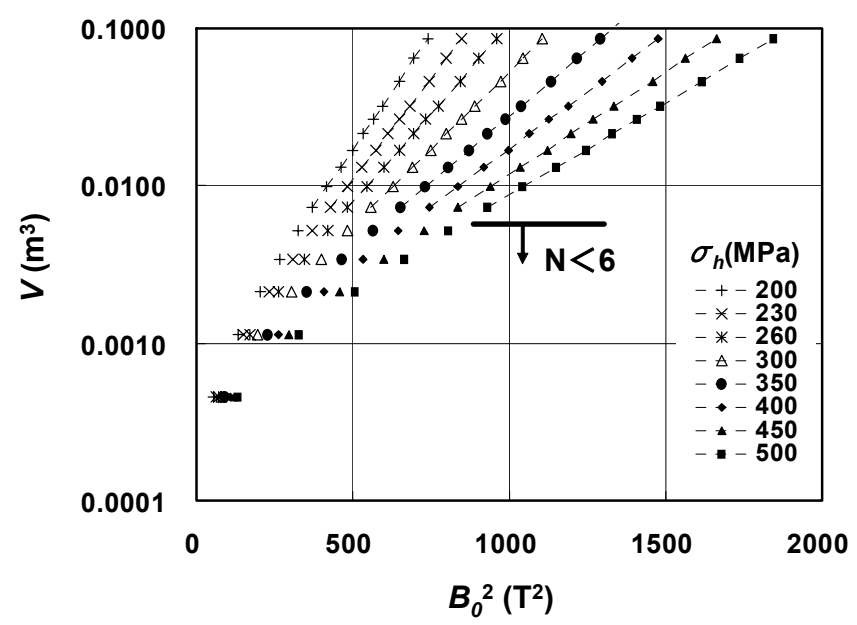

Fig. 13 Relationship between $\boldsymbol{B}_{\boldsymbol{0}}$ and coil volume.

但し、 $\mathbf{N}<6$ の低磁場領域では Fig. 13 に示すように $\boldsymbol{B}_{\boldsymbol{0}}$ 依存性が小さくなり、(1)式の関係からずれることが明らか になった。

この結果を整理すると $\boldsymbol{B}_{\boldsymbol{0}}$ とコイル体積の関係は次の式 で近似することができる。

$$
V=V_{c 1} \times e^{V_{c 2} \cdot B_{0}{ }^{2}}
$$

この係数 $V_{c 1} 、 V_{c 2}$ と $\sigma_{h}$ との関係を Fig. 14 に示す。 $V_{c 1}$ は $\sigma_{\boldsymbol{h}}$ に依存せずに一定值を取り、 $\boldsymbol{V}_{\boldsymbol{c} 2}$ は $\sigma_{\boldsymbol{h}}$ に反比例す る。これらをまとめると次の近似式で表すことができる。

$$
V=5.85 \times 10^{-4} \times e^{\frac{1.35}{\sigma_{h}} B_{0}^{2}}
$$

この式を使えば発生させたい磁場と $\sigma_{\boldsymbol{h}}$ の基準だけでコ イル体積を求めることができ、密度をかければ導体の質量 を得ることができる。このモデルマグネットは巻き枠を無
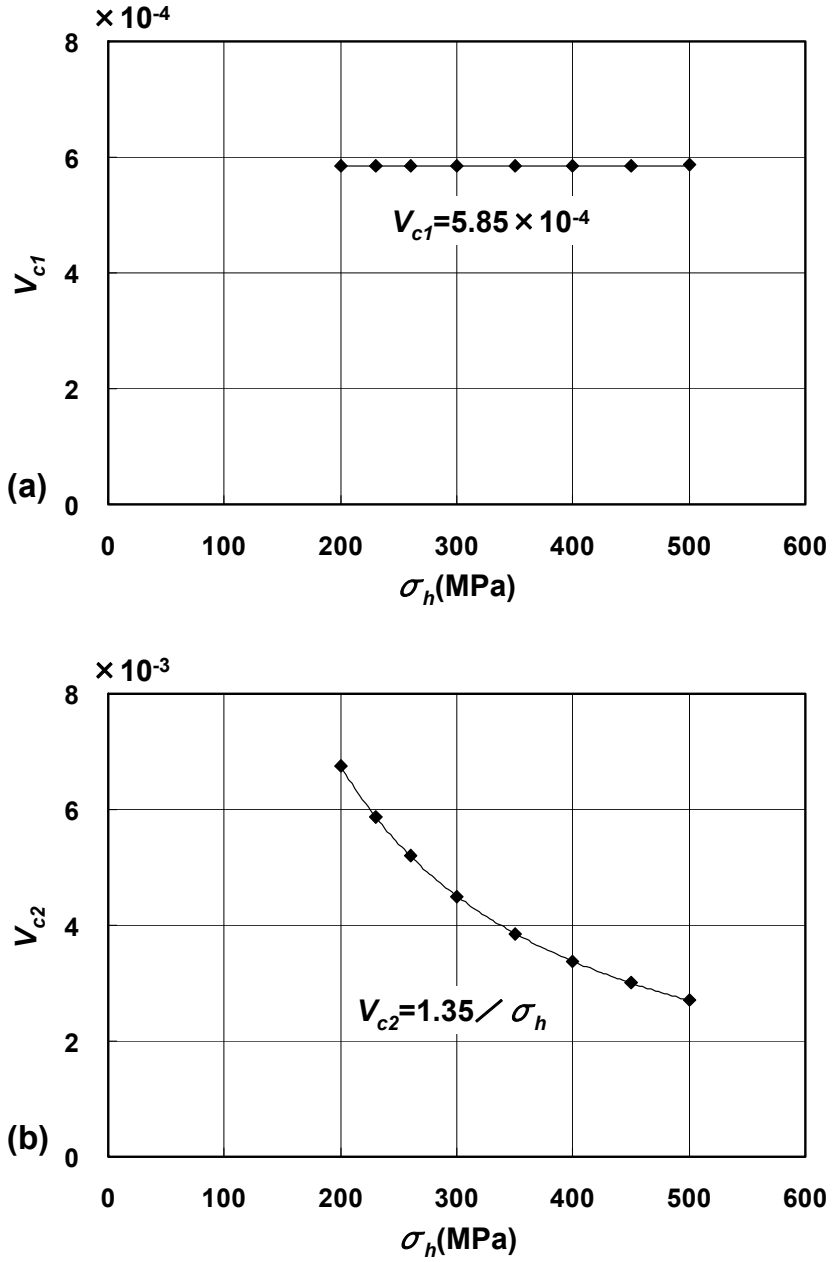

Fig. $14 \sigma_{h}$ dependence of coefficients $V_{c 1}$ (a) and $\boldsymbol{V}_{\boldsymbol{c} 2}(\mathrm{~b})$.

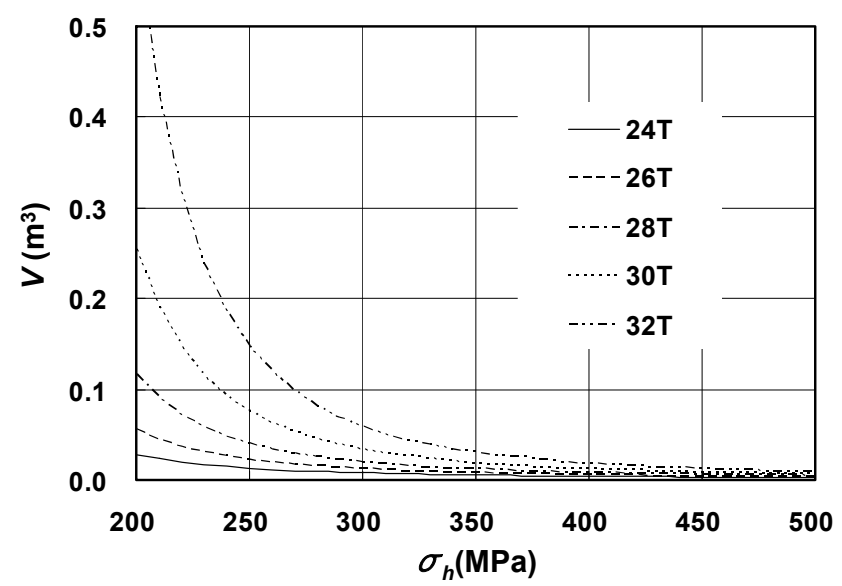

Fig. 15 Relationship between $\sigma_{h}$ and coil volume.

視した理想状態での設計值であり、これ以下にすること は不可能という限界值を示していることになる。

今回得られた結果を用いて 24〜32 T の高磁場マグネッ トについて、コイル体積が $\sigma_{\boldsymbol{h}}$ の基準でどのように変化す 
るかを示したのが Fig. 15 である。この図を見て判るよう に $24 \mathrm{~T}$ マグネットの場合、 $\boldsymbol{\sigma}_{\boldsymbol{h}}=300 \mathrm{MPa}$ が $\boldsymbol{\sigma}_{\boldsymbol{h}}=200 \mathrm{MPa}$ と なることでコイル体積は 3.7 倍になるが、30 T マグネット では 7.6 倍にもなる。この傾向は高磁場になる程顕著に なってくる。コイル体積が大きいことは必要となる超伝導 線材の量が多くなるだけでなく、これを納めるクライオス タットも大きくなることを意味している。

これらを考慮すると $30 \mathrm{~T}$ 級マグネットを実現するため には、高い $\boldsymbol{\sigma}_{\boldsymbol{h}}$ を設計基準とし小型軽量化を図る必要があ る。これを可能にするには超伝導線材自身の高強度化が不 可欠で、臨界電流と補強材の最適化が必要であろう。ま た、マグネットの製造においては高 $\sigma_{\boldsymbol{h}}$ 化により深刻化す るワイヤームーブメントを防止し、クエンチ対策を十分に 検討していかなければならない。更には、これを実現でき る製造方法を確立することが重要になる。

\subsubsection{B 3 と蓄積エネルギー}

$\boldsymbol{B}_{\boldsymbol{0}}$ と蓄積エネルギーの間にも Fig. 16 に示すように $\boldsymbol{B}_{\boldsymbol{0}}$ と コイル体積と同様の関係がある。

この結果を整理すると $\boldsymbol{B}_{\boldsymbol{0}}$ と蓄積エネルギーの関係は次 の式で近似することができる。

$$
E=E_{c 1} \times e^{E_{c 2} \cdot B_{0}{ }^{2}}
$$

この係数 $\boldsymbol{E}_{\boldsymbol{c} 1} 、 \boldsymbol{E}_{\boldsymbol{c} 2}$ と $\boldsymbol{\sigma}_{\boldsymbol{h}}$ との関係を Fig. 17 に示す。

$\boldsymbol{E}_{\boldsymbol{c} 1}$ は $\sigma_{\boldsymbol{h}}$ に比例し、 $\boldsymbol{E}_{\boldsymbol{c} 2}$ は $\sigma_{\boldsymbol{h}}$ に反比例する。これらを まとめると次の近似式で表すことができる。

$$
E=\left(2.25 \times 10^{-4} \times \sigma_{h}\right) \times e^{\frac{1.38}{\sigma_{h}} B_{0}{ }^{2}}
$$

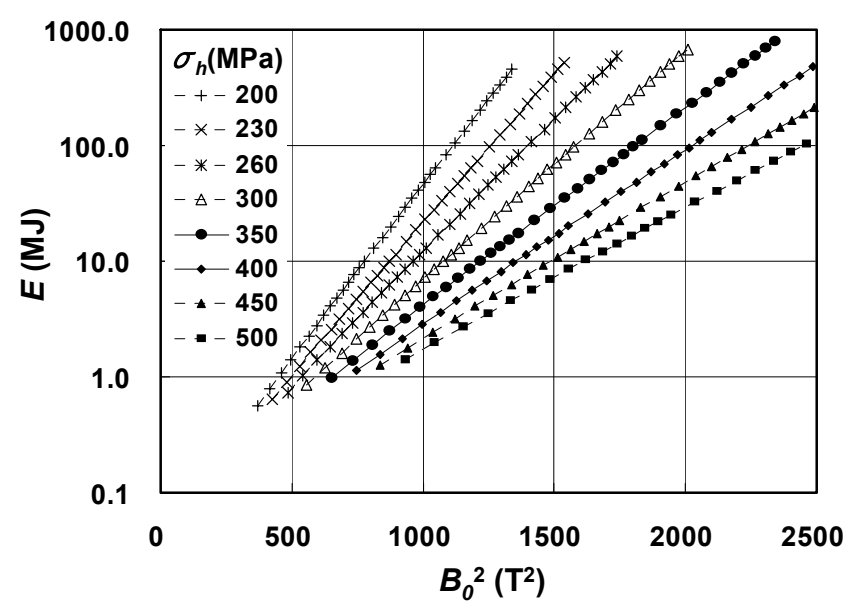

Fig. 16 Relationship between $\boldsymbol{B}_{0}$ and stored energy.
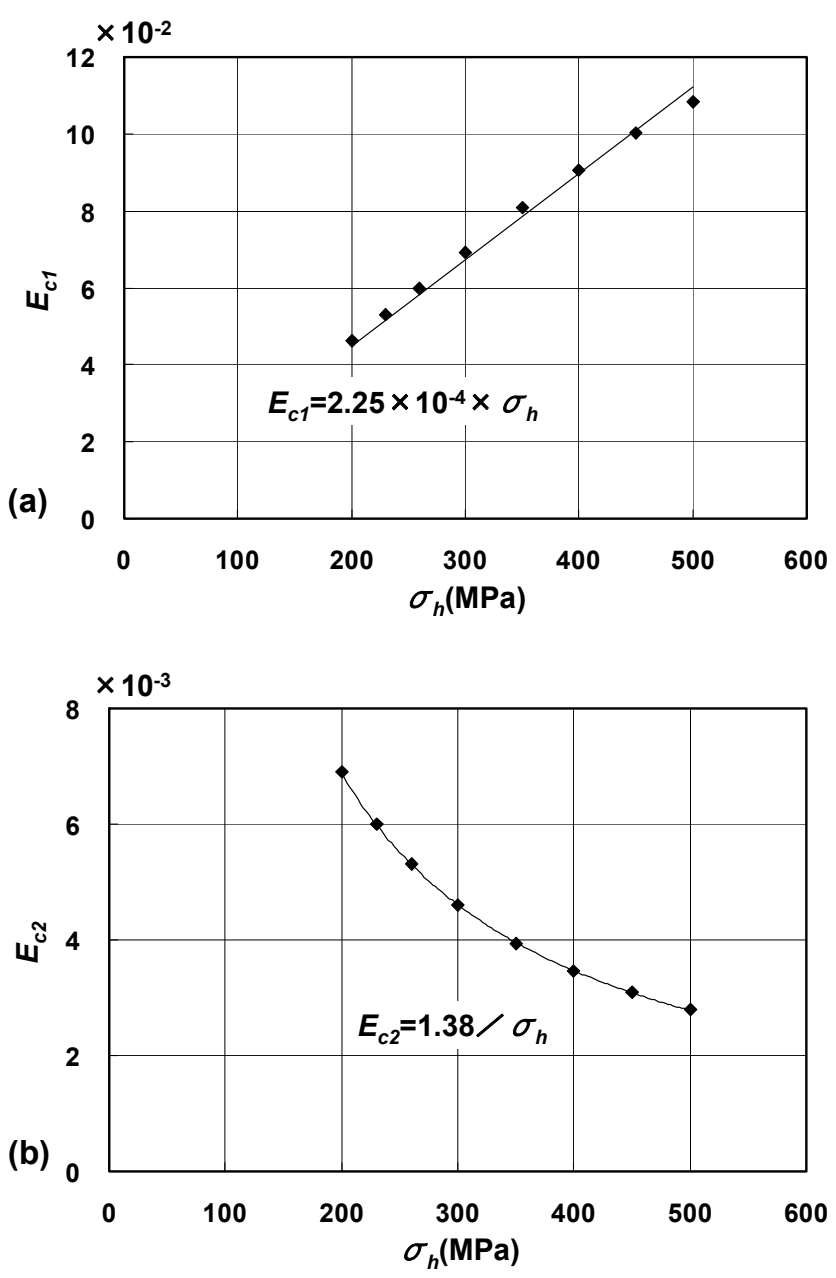

Fig. $17 \sigma_{h}$ dependence of coefficients $\boldsymbol{E}_{\boldsymbol{c} 1}$ (a) and $\boldsymbol{E}_{\boldsymbol{c} 2}$ (b).

\section{2.4 コイル体積と蓄積エネルギー}

コイル体積および蓄積エネルギーの $\sigma_{\boldsymbol{h}}$ 依存性を示す(6) 式と(8)式から、これらの間には Fig. 18 に示すような比例 関係があることが判る。比例係数 : K は Fig. 19 に示すよう に $\sigma_{\boldsymbol{h}}$ に比例する。

これらの関係をまとめると次の近似式で表すことができ る。

$$
E=0.462 \times \sigma_{h} \times V
$$

コイルが銅でできていると考えて、コイル体積を質量に 置き換えると蓄積エネルギーとコイル質量 : $\boldsymbol{W}$ の関係は

$$
E / W(J / k g)=51.8 \times \sigma_{h}
$$

となる。 


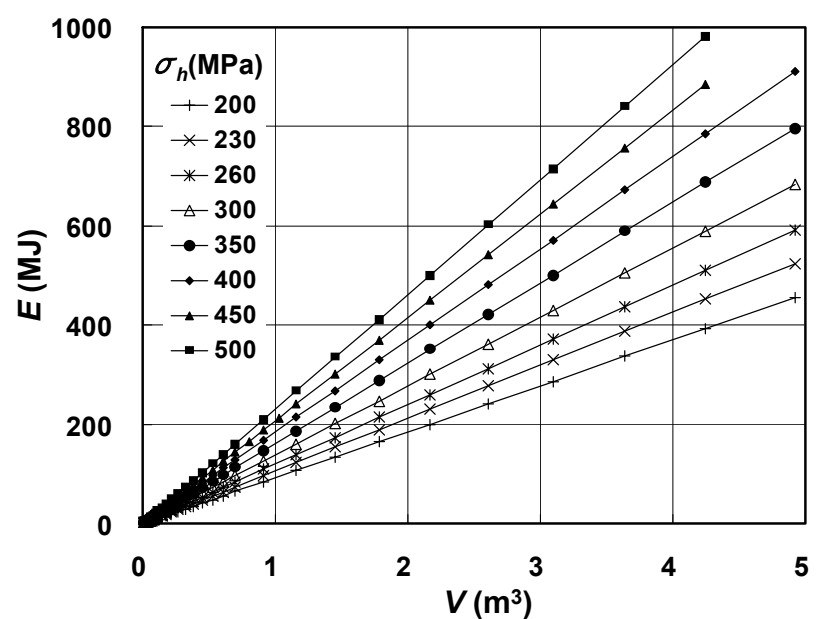

Fig. 18 Relationship between coil volume and stored energy.

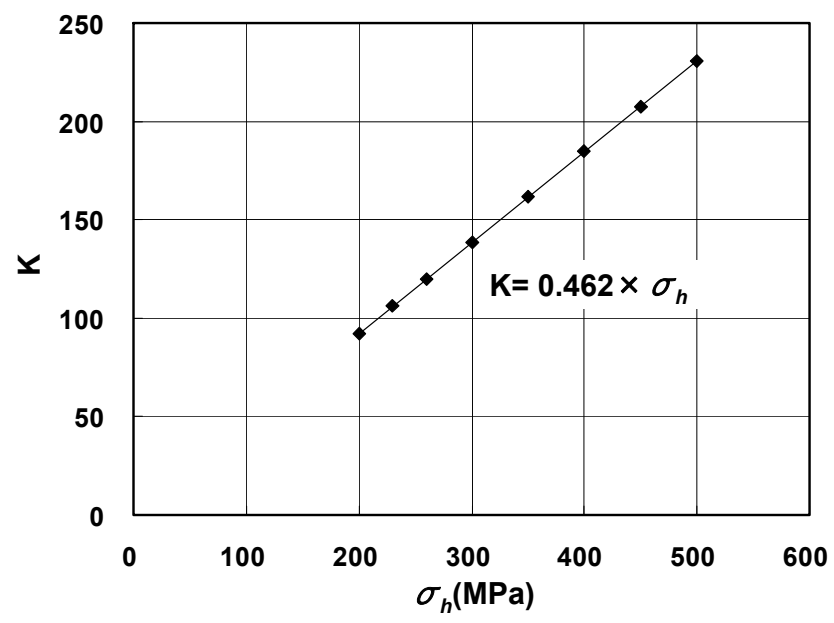

Fig. $19 \sigma_{h}$ dependence of $\mathbf{K}$.

マグネットがクエンチした時、全てのエネルギーがマグ ネット自身の温度上昇に使われた場合のマグネットの最大 温度 : $\boldsymbol{T}_{\boldsymbol{m a x}}$ は、この式で得られる值と銅のエンタルピーを 比較することで求めることができる。得られた結果を Fig. 20 に示す。

本モデルでは、 $\boldsymbol{T}_{\boldsymbol{m a x}}$ は $\boldsymbol{\sigma}_{\boldsymbol{h}}$ のみを変数とする結果を導 く。 $\sigma_{\boldsymbol{h}}$ が大きい程マグネット温度は高くなるが、 $\boldsymbol{\sigma}_{\boldsymbol{h}}=500$ $\mathrm{MPa}$ の場合でも $\boldsymbol{T}_{\boldsymbol{m a x}}$ は約 $150 \mathrm{~K}$ にとどまることが判った。 但し、この值はマグネット全体が一様に温度上昇した場合 の值で、局所的なホットスポットの温度ではない。

\section{2.5 漏洩磁場}

漏洩磁場との関連性についても解析を行った。漏洩磁場 の指標として磁場中心から $\boldsymbol{B}=0.5 \mathrm{mT}$ までの距離が使われ ることが多い。そこで $\boldsymbol{B}_{\boldsymbol{0}}$ と $\mathrm{Z}$ 軸方向 $0.5 \mathrm{mT}$ 地点との関係 を Fig. 21 に示す。この図は $\boldsymbol{B}_{\boldsymbol{0}}$ とコイル体積と同様の関係 があることを示している。

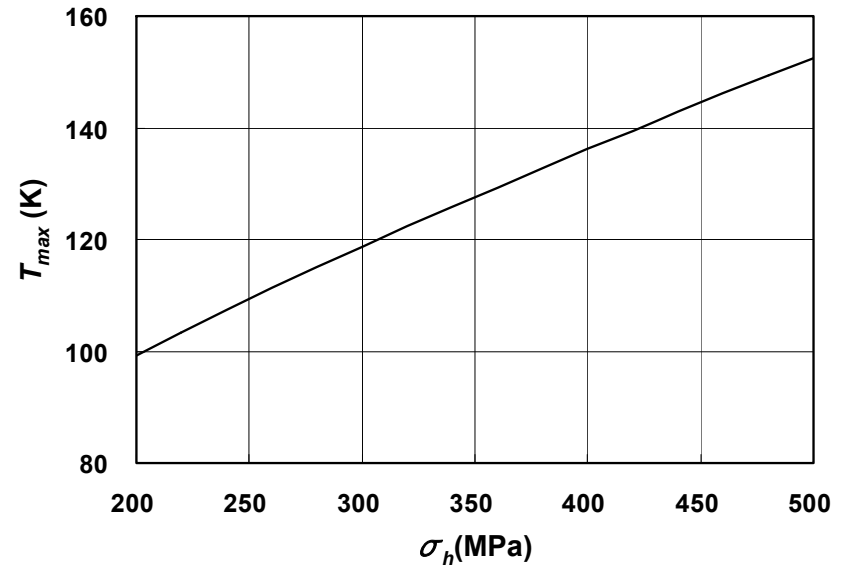

Fig. 20 Relationship between $\sigma_{h}$ and $\boldsymbol{T}_{\boldsymbol{m a x}}$.

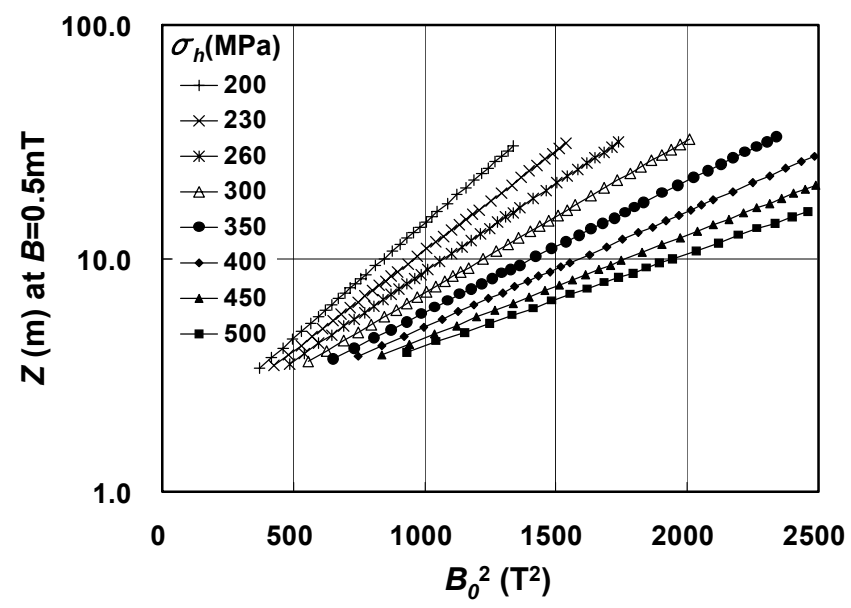

Fig. 21 Relationship between $\boldsymbol{B}_{\boldsymbol{\theta}}$ and $\boldsymbol{Z}$ at $\boldsymbol{B}=0.5 \mathrm{mT}$.

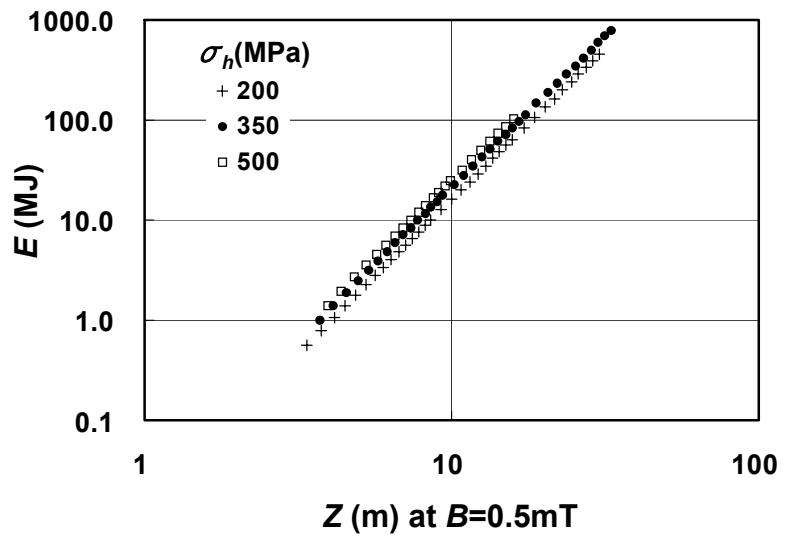

Fig. 22 Relationship between $\boldsymbol{Z}$ at $\boldsymbol{B}=0.5 \mathrm{mT}$ and stored energy.

この $0.5 \mathrm{mT}$ 地点と蓄積エネルギーとの相関を Fig. 22 に 示す。これは蓄積エネルギーが $0.5 \mathrm{mT}$ 地点の $\mathrm{n}$ 乗に比例す ることを意味している。 $\mathrm{n}$ は 3.04 3.07 の值で、 $\boldsymbol{\sigma}_{\boldsymbol{h}}$ との相 


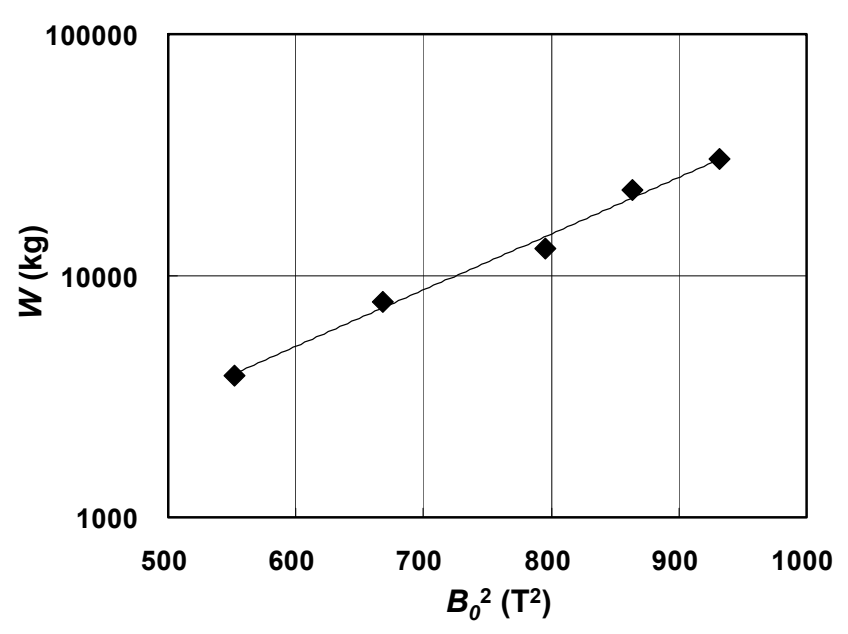

Fig. 23 Relationship between $\boldsymbol{B}_{\boldsymbol{0}}$ and weight of superconductors.

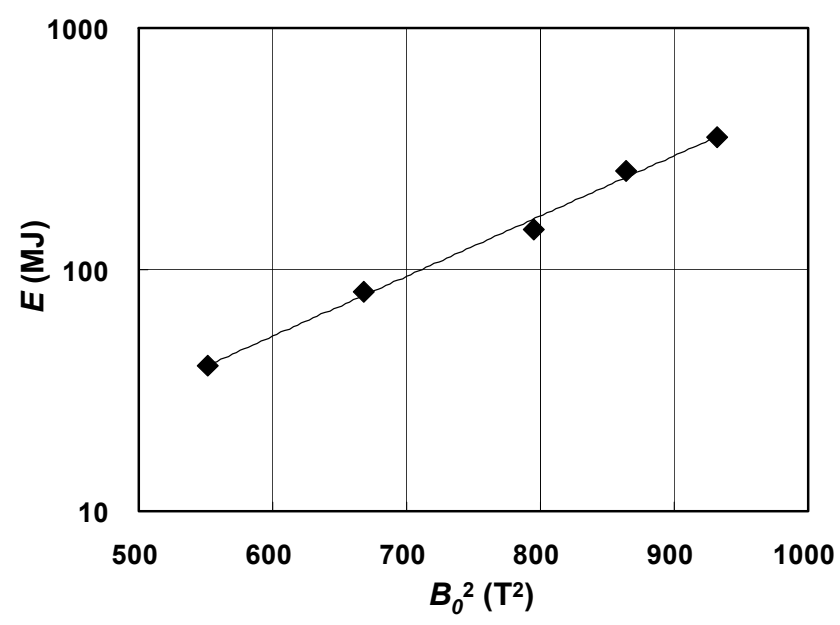

Fig. 24 Relationship between $\boldsymbol{B}_{\boldsymbol{0}}$ and stored energy.

関は小さい。

単純な磁気双極子モーメントの場合、漏洩磁場の距離は 磁気双極子モーメントの大きさの 3 乗根に比例するが、有 限な大きさを持つ実際のマグネットでは中心磁場の大きさ ではなく蓄積エネルギーの 3 乗根に比例することが判っ た。

\section{4. マグネット設計例への適用}

第 3 章で得られた相関関係を第 2 章で示したマグネット 設計例に適用してみる。中心磁場と線材質量および蓄積エ ネルギーの相関をそれぞれ Fig. 23 と Fig. 24 に示す。これ らの図では横軸を $\boldsymbol{B}_{\boldsymbol{0}}$ の 2 乗で、縦軸を対数でプロットして いる。

これらの図を見ると $\sigma_{h}$ 一定のモデルマグネットで成立 した規則性が、実際のマグネット設計にもほぼ当てはまる
ことを示している。この規則性を使えば中心磁場を指定す るだけでマグネットの概要を把握することが可能になる。

\section{5. まとめ}

$\sigma_{h}$ の上限が一定值以下という条件を設けて $25 \sim 30 \mathrm{~T}$ 規 模の高磁場マグネットの基本設計を行った。その結果、マ グネット（線材）質量および蓄積エネルギーが非常に強い 磁場依存性を示すことが判った。そこでこれらの相関を解 析するため、複数個のコイルから成るある理想的なモデル マグネットを設定し、全てのコイルの $\sigma_{h}$ max $_{\text {max }}$ が同じ值にな るという条件下で磁場計算を行った。

この計算によるとマグネットの電流密度は超伝導線の臨 界電流值よりもむしろ $\sigma_{\boldsymbol{h}}$ により制約を受けることが判っ た。また、コイル外径、コイル体積、蓄積エネルギー、漏 洩磁場などの重要な諸元と中心磁場との間に規則性がある ことが判った。それは、これらの諸元が中心磁場の 2 乗の 指数関数に比例するというものである。この規則性の一部 については無限長の多層コイルの場合に指摘されていた が、超伝導マグネットに適用して具体的な計算および解析 はなされていなかった。

更に、この規則性は高磁場マグネットの基本設計にも当 てはめることが可能であり、 $\sigma_{h}$ 一定のモデルの有効性を 示すことができた。これらの解析の結果として、マグネッ トを小型化するためには高い $\sigma_{\boldsymbol{h}}$ を基準とした設計が必要 不可欠であることが示された。

本研究は、新エネルギー・産業技術総合開発機構 ( New Energy and Industrial Technology Development Organization；NEDO）が行っている「高温超電導材料を利 用した超高磁場 NMRの実用化可能性に関する調査」にお いて実施した。

\section{参 考 文 献}

1) T. Kiyoshi, et al.: "Persistent-mode operation of a $920 \mathrm{MHz}$ highresolution NMR magnet," IEEE Trans. Appl. Supercond. 12 (2002) 711-714

2) T. Kiyoshi, et al.: "Operation of a 920-MHz high-resolution NMR magnet at TML," IEEE Trans. Appl. Supercond. 13 (2003) 13911395

3) M. Yoshikawa et al.: "Development of a $930 \mathrm{MHz}$ NMR magnet," TEION KOUGAKU 39 (2004) 625-631 (in Japanese) 吉川正敏, 他 :「930 MHz NMR マグネットの開発」, 低温工 学 39 (2004) 625-631

4) T. Kiyoshi, et al.: "Operation of a 930-MHz high-resolution NMR magnet at TML," IEEE Trans. Appl. Supercond. 15 (2005) 13301333 
5) N. Ayai, et al.: "DI-BSCCO wires by controlled over pressure sintering," Phys.: Conference Series 43 (2006) 47-50

6) V. Selvamanickam, et al.: "Recent progress in second-generation HTS conductor scale-up at SuperPower," ASC2006 Materials Abstracts 2MB02

7) W. Denis Markiewicz, et al.: "Perspective on a superconducting 30 T/1.3 GHz NMR spectrometer magnet," IEEE Trans. Appl. Supercond. 16 (2006) 1523-1526

8) M. Date: "Submillimeter electron spin resonance I . A new method of high magnetic field generation,” J. Phys. Soc. Jpn. 39 (1975) 892-897

9) H. Kitaguchi, et al.: "High field performance of CT-OP Bi-2223 tapes," TML annual rep. (2005) 81-82

10) L. Del Frate, et al.: "Novel muon cooling channels using hydrogen refrigeration and high temperature superconductor," IEEE Proceedings of 2005 Particle Accelerator Conference, (2005) 3126-3128

11) 超電導工学研究所提供データ (PLD-YBCO/IBAD 総厚み $\sim 123.5 \mu \mathrm{m} 、 \mathrm{YBCO} 2.25 \mu \mathrm{m} 、 \mathrm{Ag} 20 \mu \mathrm{m})$
大 塚 昭 弘 1958 年 1 月 2 日生。1981 年大阪大学理学部 物理学科卒業。1 1983 年大阪大学大学院理学研究科物理学専攻前 期課程修了。同年 4 月(侏神戸製鋼所入社。1 1989 年 11 月ジャパン マグネットテクノロジー株（現ジャパンスーパーコンダクタテク ノロジー(㑣) 一出向。2005 年より独立行政法人物質・材料研究 機構に出向。主として超伝導マグネットの開発に従事。低温工学 協会会員。

木吉 司 1959 年 8 月 4 日生。1983 年東京大学工学部 原子力工学科卒業。1988 年同大学大学院工学系研究科博士課程 修了。同年 4 月より科学技術庁金属材料技術研究所（現独立行政 法人物質 - 材料研究機構）勤務。現在、同機構超伝導材料セン ターマグネット開発グループグループリーダー。主として強磁場 超伝導マグネットの開発に従事。低温工学協会、日本金属学会、 日本 MRS、応用物理学会、日本磁気科学会会員。工学博士。 